\title{
Toxoplasma Gondii and Neospora Caninum Antibodies in Backyard Chickens in Rio Grande do Sul, Brazil
}

http://dx.doi.org/10.1590/1516-635x1702263-265

Technical Note

\section{author(s)}

Camillo $\mathrm{G}^{\prime}$

Cadore $\mathrm{GC}^{\prime}$

Ferreira MST

Braünig $P$

Maciel JF'

Pivoto $\mathrm{FL}^{\prime}$

Sangioni LA'

Vogel FSF

Laboratório de Doenças Parasitárias dos Animais Domésticos, Departamento de Medicina Veterinária Preventiva (DMVP), Universidade Federal de Santa Maria (UFSM), Santa Maria, RS 97105-900, Brazil.

\section{-Mail Address}

Corresponding author e-mail address Camillo G

Laboratório de Doenças Parasitárias dos Animais Domésticos, Departamento de Medicina Veterinária Preventiva (DMVP) Universidade Federal de Santa Maria (UFSM), Santa Maria, RS 97105-900, Brazil. Fone: 055-32208071.

E-mail: giovanacamillo@yahoo.com.br

\section{-Keywords}

Backyard chickens, Neosporosis, Public health, Toxoplasmosis.

\section{ABSTRACT}

Toxoplasma gondii and Neospora caninum are two intracellular apicomplexan protozoa with worldwide distribution, and are responsible for reproductive disorders in sheep and cattle. These protozoa may infect a wide variety of domestic and wild animals, including birds, and backyard chickens can be used as sentinels of their infection. Parasites investigation in backyard chickens may be useful for the evaluation of environmental contamination with oocysts, of the disease cycle, and of risk factors associated with public health. The aim of this study was establish the importance of backyard chickens as $T$. gondii and $N$. caninum hosts. A number of 137 serum samples were collected from chickens in 23 farms in Rio Grande do Sul State, Brazil, and tested for toxoplasmosis and neosporosis by indirect fluorescence antibody test (IFAT). Anti-Toxoplasma and anti-Neospora antibodies were detected in 20 (87\%) farms. Total prevalence of $T$. gondii was $74.4 \%(102 / 137)$ and $36.5 \%(50 / 137)$ for $N$. caninum, while $12.4 \%$ $(17 / 137)$ of the chickens were positive for both protozoa. The results show that backyard chicken can used as indicators of the presenced of the protozoa $N$. caninum and T. gondii, emphasizing yours importance in the public health. Considering the high prevalence of toxoplasmosis in backyard chickens in the region, control measures should be taken to prevent transmission of the infection to the animals and humans.

\section{INTRODUCTION}

Toxoplasma gondii and Neospora caninum are two apicomplexan protozoa and are biologically similar, and present worldwide, and cause reproductive failure in small ruminants and cattle (Dubey, 2002; Dubey \& Schares, 2011). Toxoplasmosis is a parasitic zoonosis that affects a wide range of animals, including birds and man (Dubey, 2009). Neosporosis is important cause of abortion in cattle and has significant economic impact in the dairy and beef industries (Trees et al., 1999). T. gondii infections are prevalent in many avian species and can cause mortality in some species of birds (Dubey et al., 2010). N. caninum has been found in a few species of naturally-infected birds, and particularly in domestic chicken (Costa et al., 2008) and in some wild birds (Darwich et al., 2012). Chickens are intermediate hosts, especially those reared in backyard systems, where transmission occurs by the ingestion of oocysts from the soil that were shed by dogs and cats, which are the definitive hosts of $N$. caninum and $T$. gondii, respectively (Gondim, 2006; Dubey, 2009). For this reason, backyard chickens are considered indicators of the environmental contamination with oocysts (Furuta et al., 2007; Dubey, 2009). In order to help understanding the role of chickens in the epidemiology these protozoa, the aim of the present study was estimate the seroprevalence of $T$. gondii and $N$. caninum in backyard chickens in southern Brazil. 
Camillo G, Cadore GC, Ferreira MST, Braünig P, Maciel JF, Pivoto $\mathrm{FL}$, Sangioni LA, Vogel FSF
Toxoplasma Gondii and Neospora Caninum Antibodies in Backyard Chickens in Rio Grande do Sul, Brazil

\section{MATERIALS AND METHODS}

Serum samples were collected from 137 clinically healthy backyard chickens from 23 farms in Rio Grande do Sul State, Brazil, between May and November 2011. Blood samples were collected by wing puncture. All samples were tested by indirect fluorescence antibody test (IFAT), for detection of $T$. gondii and $N$. caninum antibodies. The IFAT cut-off for T. gondii was 1:16 (Garcia et al., 2000) and 1:50 for N. caninum (Costa et al., 2008). The serum samples were diluted in phosphate buffered saline solution (PBS - 0.1M phosphate, 0.33M $\mathrm{NaCl}, \mathrm{pH}$ 7.2), and positive and negative chickens for both protozoa were used as controls. IFAT was applied following the procedure described by Camargo et al. (2001). T. gondii and N. caninum tachyzoites,, strains $\mathrm{RH}$ and NC-1 strains, respectively, were used as antigens., using. The commercial fluoresceinlabeled anti-chicken $\lg { }^{\odot}$ (Sigma, St Louis, USA) was used as secondary antibody. Slides were read at x400 magnification under a fluorescence microscope (Leica CTR 4000/EBQ 100, Leica Microsystems, Germany). Samples with titers greater than 16 and 50 were considered positive for toxoplasmosis and neosporosis, respectively.

All procedures of animal handling and experimentation were performed under veterinary supervision and according to guidelines of Institutional Ethics and Animal Welfare Committee (UFSM, approved under protocol \#009/2011).

\section{RESULTS AND DISCUSSION}

Anti-Toxoplasma and anti-Neospora antibodies were detected in 20 (87\%) of the 23 farms. In 19 (82.6\%) out of the 23 farms, antibodies against $T$. gondii were detected, while anti- $N$. caninum were detected in 14 $(60.9 \%)$ out of the 23 farms. In the backyard chickens tested, antibodies against $T$. gondii were detected in $74.4 \%(102 / 137)$ chickens and against $N$. caninum in $36.5 \%$ (50/137) chickens. Mixed infections were found in 17 out of 137 backyard chickens tested (12.4\%), and in $13(56.5 \%)$ of the 23 farms. Therefore, 85 (62\%) and $33(24.1 \%)$ of the serum samples were positive only for $T$. gondii and $N$. caninum, respectively.

Higher antibody titers against $T$. gondii compared with $N$. caninum were determined in the sera of the tested chickens. Studies in different regions of Brazil showed that the seroprevalence of $T$. gondii ranged between $38 \%$ and $66 \%$ in chickens (Dubey, 2009). T. gondii infection has been extensively reported in birds, but only a few reports in backyard chickens showed their importance as hosts, which deserves further study (Tilahun et al., 2013). As for N. caninum, Costa et al. (2008) and Martins et al. (2011) found $23.5 \%$ and $39.5 \%$ positive serum samples in backyard chickens respectively, indicating significant exposure to this protozoan. These results are epidemiologically important because chickens are cosmopolitan animals consumed by many animal species, including dogs and cats which are the definitive hosts of those parasites (McAllister et al., 1998; Dubey, 2002).

Sources of infection for humans depend on local culture, geographical location, and eating habits differences, and T. gondii has been detected in different in various tissues of chickens (Tenter et al., 2000; Dubey et al., 2003; Dubey et al., 2004). T. gondii can be isolated from infected tissues of backyard chickens, and therefore, these birds may contribute for the epidemiological characterization of strains on the protozoan present in the environment (Dubey, 2009). Moreover, meat of infected backyard chickens may be a source of $T$. gondii infection of humans and animals. The presence of free-range poultry on dairy farms presenting abortions caused by neosporosis has been considered a risk factor for $N$. caninum infection in some studies (Bartels et al., 1999; Ould-Amrouche et al., 1999).

The presence of antibodies against $T$. gondii and $N$. caninum in backyard chickens may be used as an indication of the contamination of the environment with oocysts. Those birds feed on the ground and tissues of infected chickens are considered a source of infection of others animals, such as dogs and cats, allowing the life cycle of this protozoan to be completed (Costa et al., 2008; Dubey, 2009).

The presence of antibodies for both parasites indicates the environmental contamination of the evaluated farms. Although chickens can be naturally infected by these protozoa, mainly T. gondii (Dubey, 2009), further studies are necessary to define the role of chickens in epidemiology of $N$. caninum. Backyard chickens are raised in the region where farms were evaluated for meat and egg production, and these products are consumed the households. The birds are slaughtered at home or in uninspected slaughter facilities. Meat and viscera of infected backyard chickens may be an important source of infection of humans and animals when improperly handled or consumed (Dubey, 2009). Considering the results, biosecurity measures in backyard production are required to prevent human infection. In conclusion, the results of the present study suggest that backyard 
chickens can be intermediate hosts of $T$. gondi and $N$. caninum, and their possible role in the maintenance of the life cycle of these protozoan. The results indicate a widespread exposure of backyard chickens to T. gondii and $N$. caninum in the state of Rio Grande do Sul, Brazil.

\section{REFERENCES}

Bartels CJ, Wouda W, Schukken YH. Risk factors for Neospora caninum associated abortion storms in dairy herds in the Netherlands (1995 to 1999). Theriogenology 1999;52(2):247-257.

Camargo ME. Toxoplasmose. In: Ferreira AW, Ávila SLM. Diagnóstico laboratorial das principais doenças infecciosas e auto-imunes. 2nd ed. Rio de Janeiro: Guanabara Koogan; 2001. p.278-286.

Costa KS, Santos SL, Uzêda RS, Pinheiro AM, Almeida MA, Araújo FR, McAllister MM, Gondim LF. Chickens (Gallus domesticus) are natural intermediate hosts of Neospora caninum. International Journal for Parasitology 2008;38(2):157-159.

Darwich L, Cabezón O, Echevarria I, Pabón M, Marco I, Molina-López R, et al. Presence of Toxoplasma gondii and Neospora caninum DNA in the brain of wild birds. Veterinary Parasitology 2012;183(3-4):377-381.

Dubey JP. A review of toxoplasmosis in wild birds. Veterinary Parasitology 2002;106(2):121-153.

Dubey JP, Graham DH, Dahl E, Sreekumar C, Lehmann T, Davis MF, et al. Toxoplasma gondii isolates from free-ranging chickens from United States. The Journal of Parasitology 2003;89(5):1060-1062.

Dubey JP, Levy MZ, Sreekumar C, Kwoc OC, Shen SK, Dahl E, et al. Tissue distribution and molecular characterization of chickens isolates of Toxoplasma gondii from Peru. The Journal of Parasitology 2004;90(5):1015-1018.

Dubey JP. Toxoplasma gondii infections in chickens (Gallus domesticus): prevalence, clinical disease, diagnosis and public health significance. Zoonoses and Public Health 2009;57(1):60-73.
Dubey JP, Felix TA, Kwoc OC. Serological and parasitological prevalence of Toxoplasma gondii in wild birds from Colorado. The Journal of Parasitology 2010;96(5):937-939.

Dubey JP, Schares G. Neosporosis in animals - the last five years. Veterinary Parasitology 2011;180(1-2):90-108.

Furuta PI, Mineo TW, Carrasco AO, Godoy GS, Pinto AA, Machado RZ. Neospora caninum infection in birds: experimental infections in chicken and embryonated eggs. Parasitology 2007;134:1931-1939.

Garcia JL, Navarro IT, Ogawa L, Marana ERM. Soroprevalência do Toxoplasma gondii em galinhas (Gallus gallus domesticus) de criações domésticas, oriundas de propriedades rurais do norte do Paraná, Brasil. Ciência Rural 2000;30(1):123-127.

Gondim LF. Neospora caninum in wildlife. Trends in Parasitology 2006;22(6):247-252

Martins J, Kwok OC, Dubey JP. Seroprevalence of Neospora caninum in free-range chickens (Gallus domesticus) from the Americas. Veterinary Parasitology 2011;182(2-4):349-351.

McAllister MM, Dubey JP, Lindsay DS, Jolley WR, Wills RA, McGuire AM Dogs are definitive hosts of Neospora caninum. International Journal for Parasitology 1998;28(9):1473-1478.

Ould-Amrouche A, Klein F, Osdoit C, Mohammed HO, Touratier A, Sanaa $\mathrm{M}$, et al. Estimation of Neospora caninum seroprevalence in dairy cattle from Normandy. Veterinary Research 1999;30(5):531-538.

Tenter AM, Heckeroth AR, Weiss LM. Toxoplasma gondii: from animals to humans. International Journal for Parasitology 2000;6(12-13):12171258

Tilahun G, Tiao N, Ferreira LR, Choudhary S, Oliveira S, Verma SK, et al. Prevalence of Toxoplasma gondii from free-range chickens (Gallus domesticus) from Addis Ababa, Ethiopia. The Journal of Parasitology 2013;99(4):740-741.

Trees AJ, Davison HC, Innes EA, Wastling JM. Towards evaluating the economic impact of bovine neosporosis. International Journal for Parasitology 1999;29(8):1195-1200. 
